Journal of Community Based Environmental Engineering and Management, 2019, Vol. 3, No. 1: 33-40

\title{
PEMAHAMAN DAN PERSEPSI PENGHUNI PONDOK PESANTREN AL-ITTIHAD KAWASAN SANTRI PUTRA TERHADAP SANITASI
}

\author{
Astri Widiastuti Hasbiah*, Deni Rusmaya, Ade Saputra \\ Program Studi Teknik Lingkungan, Universitas Pasundan
}

\begin{abstract}
Abstrak
Pesantren Al-Ittihad yang terletak di Kabupaten Cianjur, Jawa Barat merupakan sarana pendidikan dengan fasilitas asrama bagi santri-santrinya. Kegiatan di asrama memiliki kemiripan dengan kegiatan domestik jika ditinjau dari segi sanitasinya. Untuk mempertahankan kualitas hidup dan belajar para santri, diperlukan kondisi fasilitas sanitasi yang memadai dari segi kualitas dan kuantitas. Penelitian ini bertujuan untuk mengidentifikasi kondisi fasiltas sanitasi di kawasan santri putra Pesantren Al-Ittihad berdasarkan pengamatan dan wawancara kepada penghuninya. Hasil penelitian menunjukkan bahwa sarana air bersih dan air minum masih baik, secara kualitas maupun kuantitas. Sarana air limbah masih mencukupi namun memerlukan saluran untuk pengolahan grey water. Saluran drainase sudah tersedia dengan baik, namun perlu peningkatan pemeliharaan agar tidak terjadi pendangkalan atau tertutup sampah. Dalam pengelolaan sampah, walaupun sudah terdapat pemilahan, namun masih terdapat sisa sampah yang tidak ditangani dengan baik, terutama di sekitar tempat pembuangan sampah sementara.
\end{abstract}

Kata kunci: Sanitasi pondok pesantren, asrama putra, persepsi

\section{Pendahuluan}

Sanitasi adalah suatu kebutuhan dasar manusia dalam kehidupannnya sehari-hari. Keadaan sanitasi suatu masyarakat, dapat menjadi gambaran tingkat kehidupannya. Bila sanitasinya baik, masyarakat itu dalam keadaan sejahtera (Chaerunnissa, 2014). Demikian pula sebaiknya, bila keadaan sanitasinya buruk, dapat menjadi gambaran bahwasannya masyarakat tersebut berada dalam kondisi kekurangan materil ataupun pendidikannya.

Pondok Pesantren Al-Itihad adalah suatu fasilitas pendidikan berbasis agama Islam yang terletak di Desa Bojong, Kecamatan Karangtengah, Kabupaten Cianjur, Provinsi

${ }^{*}$ Penulis Korespondensi:

E-mail: astrihasbiah@unpas.ac.id

Diterima pertama kali: 7 Januari 2019

Direvisi : 21 Januari 201

Disetujui untuk publikasi: 23 Januari 2019
Jawa Barat. Pesantren yang berdiri di atas tanah seluas $11.000 \mathrm{~m}^{2}$ ini membawa misi mengembangkan ilmu pengetahuan keagamaan (Diniyah) yang berorientasi kepada penguasaan kitab salaf (kuning) sebagai ciri pokok pesantren, Bahasa Arab dan Bahasa Inggris. Dengan misi seperti itulah kemudian pesantren ini mengalami perkembangan dari tahun ke tahun. Pondok pesantren ini mengelola lembaga pendidikan setingkat SMP, SMA, dan SMK.

Tujuan khusus penelitian ini adalah untuk mengidentifikasi sarana sanitasi berdasarkan pengamatan dan pendapat penghuni dalam upaya mencari solusi perbaikan dan pengembangan sanitasi dasar seperti sarana penyediaan air bersih, sarana pembuangan limbah domestik, sarana pembuangan sampah sehingga dapat meningkatkan pola hidup sehat dalam menunjang proses belajar mengajar di Pondok Pesantren Al-Ittihad. 


\section{Metodologi}

\section{Lokasi}

Pondok Pasantren Al-Itihad adalah pondok pasantren yang terletak di Desa Bojong, Kecamatan Karangtengah, Kabupaten Cianjur, Provinsi Jawa Barat, dengan jumlah santri sebanyak 3247.

Tujuan utama pendidikan adalah mengangkat derajat manusia agar menjadi insan yang bermartabat. Tentunya hal ini harus melalui proses pembelajaran yang baik. Pembelajaran yang baik hanya dapat diwujudkan dengan sarana dan prasarana yang cukup dan layak. Diawali dengan kemauan para guru dan santri, Sarana dan model pembelajaran yang layak hingga suasana lingkungan sekolah yang sehat dan nyaman.

Gambar 1 memperlihatkan wilayah studi penelitian.

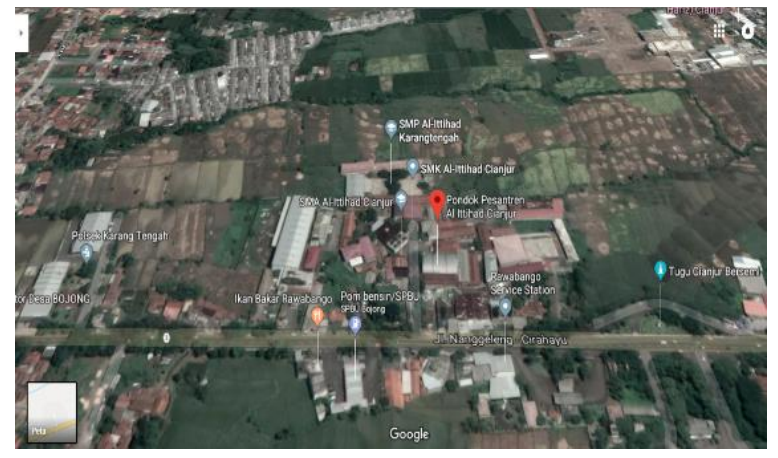

Gambar 1. Pondok Pesantren Al-Ittihad sebagai lokasi wilayah penelitian

\section{Jenis Metode Penelitian}

Metode yang digunakan dalam perencanaan ini adalah metode deskriptif yang biasa digunakan dalam pengumpulan data, baik data primer maupun data sekunder. Pelaksanaan pengumpulan data dilakukan dalam bentuk teknik survey dengan kuisioner dan pengamatan di lapangan.

\section{Pengumpulan Data Primer}

Data primer diperoleh melalui beberapa cara yaitu penyebaran kuisioner, wawancara dan pengamatan langsung di lapangan.

- Kuisioner

Kuisioner digunakan untuk mendapatkan data sanitasi baik dalam bentuk kualitas dan kuantitas. Kuisioner diberikan kepada para santri dan guru yang berdasarkan jumlahnya dianggap dapat mewakili keseluruhan populasi guru dan santri pondok pesantren dengan persamaan Slovin (Sevilla \& al, 2007) untuk menentukannya.

$$
\begin{aligned}
& n=\frac{N}{1+N e^{2}} \\
& f i=\frac{N i}{N} \\
& n i=f i \times n
\end{aligned}
$$

- Observasi

Observasi digunakan sebagai data pendukung yang bersifat kualitatif.

- Wawancara

Wawancara dilakukan kepada santri dan guru yang dianggap mengerti mengenai sanitasi untuk mendapatkan informasi yang lebih akurat.

\section{Pengumpulan Data Sekunder}

Pengumpulan data sekunder dilakukan dengan mendapatkan informasi yang dibutuhkan dari catatan atau rekaman yang dimiliki oleh instansi setempat dan lokasi penelitian.

- Data populasi penduduk pesantren

Data populasi penduduk pondok pesantren digunakan untuk berbagai keperluan, diantaranya adalah kebutuhan sarana dan prasarana sanitasi.

- Gambar denah pondok pesantren Gambar denah pondok pesantren digunakan sebagai dasar penempatan 
sarana dan prasarana perencanaan sanitasi.

- Data sarana dan prasarana sanitasi Data sarana dan prasarana sanitasi diperlukan untuk meminimalisir kesalahan perencanaan yang akan dilakukan terhadap kondisi sanitasi eksisting.

- Indentifikasi data sanitasi.

\section{Hasil dan Pembahasan}

\section{Penentuan Jumlah Responden Kuisoner}

Masalah sanitasi yang terjadi di daerah studi diketahui dari hasil pengamatan dan survey serta penyebaran kuisioner terhadap santri dan pegawai pemelihara sarana prasarana di Pondok Pesantren Al-Ittihad Kabupaten Cianjur. Total santri yang terdapat di pondok pesantren 1462 orang.

Perhitungan kuisioner dilakukan untuk mendapatkan sampel responden dengan cara metode perhitungan Slovin.

Contoh Perhitungan :

$$
\begin{aligned}
& n=\frac{N}{1+N e^{2}} \\
& n=\frac{N}{1+N e^{2}}=\frac{1462}{1+1462 \times 0,1^{2}} \\
& =93,59 \text { Responden }=94 \text { Responden }
\end{aligned}
$$

Jumlah proporsional untuk tiap tingkat sekolah.

$$
\begin{aligned}
& f i=\frac{N i}{N} \\
& \mathrm{ni}=\mathrm{fi} \times \mathrm{n}
\end{aligned}
$$

SMP Plus $=815$ santri

$$
\begin{aligned}
& n i=\frac{815}{1462}=0,55 \times 94=52 \text { Responden } \\
& >\text { SMA Plus }=283 \\
& n i=\frac{283}{1462}=0,19 \times 94=18 \text { Responden }
\end{aligned}
$$

SMK Terpadu $=364$

$$
\begin{aligned}
& n i=\frac{364}{1462}=0,25 \times 94= \\
& 24 \text { Responden }
\end{aligned}
$$

Setelah melakukan perhitungan menggunakan rumus Slovin, maka didapat jumlah sampel pada tiap tingkat pendidikan seperti pada Tabel 1.

Tabel 1. Jumlah Sampel Responden

\begin{tabular}{ll}
\hline $\begin{array}{l}\text { Tingkat } \\
\text { Pendidikan }\end{array}$ & $\begin{array}{l}\text { Jumlah } \\
\text { Sampel }\end{array}$ \\
\hline SMP Plus & 52 \\
\hline SMA Plus & 18 \\
\hline SMK Terpadu & 24 \\
\hline Total & 94 \\
\hline
\end{tabular}

\section{Analisis Sarana Air Bersih}

Beberapa hasil pengumpulan pendapat melalui penyebaran kuisioner mengenai sarana air bersih bisa dilihat pada Gambar 2 di bawah ini.

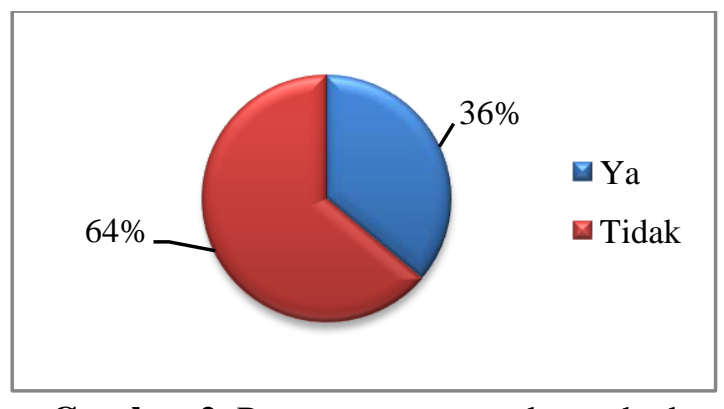

Gambar 2. Pernyataan responden terhadap kualitas air parameter rasa.

Gambar 2 tersebut menunjukkan bahwa dari 94 responden yang menjawab bahwa air minum tidak memiliki rasa yaitu sebanyak $64 \%$, dan yang menjawab bahwa air minum memiliki rasa sebanyak 36\%. Sehingga perlunya melakukan peninjauan ulang pada pengolahan air tersebut, baik dalam unit pengolahannya, bak penampungannya maupun saluran penerimanya.

Gambar 3 memperlihatkan pernyataan responden mengenai proses memasak air minum sebelum dikonsumsi. 


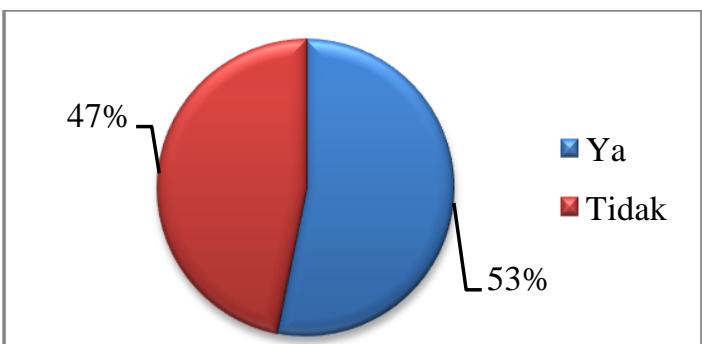

Gambar 3. Pernyataan responden mengenai apakah air minum dimasak terlebih dahulu sebelum dikonsumsi.

Gambar 3 tersebut menunjukkan bahwa dari 94 responden yang menjawab bahwa air minum yang digunakan tidak dimasak terlebih dahulu (langsung diminum) yaitu sebanyak $47 \%$, karena di pondok pesantren memiliki sistem pengolahan air menggunakan desinfeksi sinar UV yang diolah secara RO (reverse osmosis), sehingga dapat diminum langsung. Rangkaian sinar UV dan RO sering digunakan sebagai pengolah air untuk siap dikonsumsi (Ismillayli, Mardiana, Kurnianingsih, Hermanto, \& Fahrurazi, 2018). Sedangkan yang menjawab bahwa air minum yang digunakan dimasak terlebih dahulu sebanyak $53 \%$.

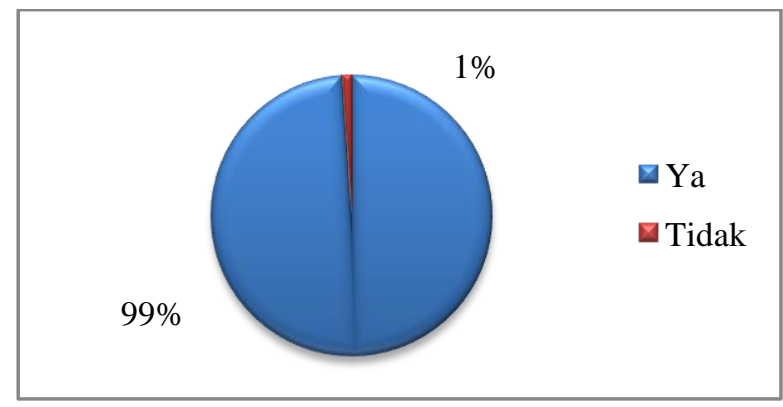

Gambar 4. Pernyataan responden terhadap layak tidaknya fasilitas air bersih.

Gambar 4 memperlihatkan bahwa dari 94 responden yang menjawab bahwa air bersih yang ada tidak layak digunakan yaitu sebanyak $1 \%$, dan yang menjawab bahwa air bersih yang ada layak digunakan sebanyak 99\%. Dapat disimpulkan bahwa tidak terdapat masalah yang signifikan untuk kelayakan air bersih di Pondok Pesantren Al-Ittihad.

\section{Analisis Sarana Air Limbah}

Hasil penyebaran kuisioner untuk akses air limbah bisa dilihat pada Gambar 5.

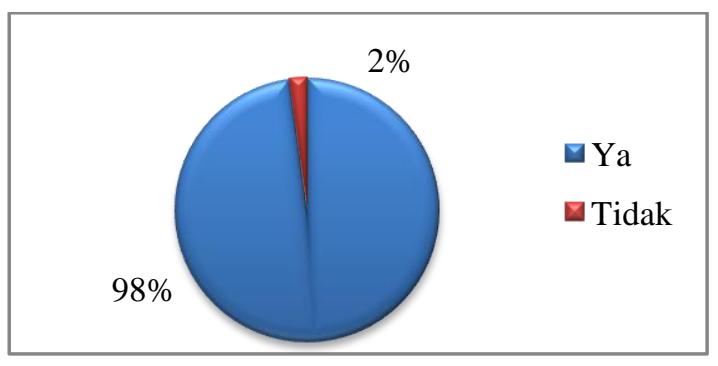

Gambar 5. Pernyataan responden mengenai ketersediaan jamban/toilet.

Gambar 5 menunjukkan bahwa dari 94 responden yang menjawab bahwa pondok pesantren tidak memiliki jamban/ toilet yaitu sebanyak $2 \%$, dan yang menjawab bahwa pondok pesantren memiliki jamban/ toilet sebanyak 98\%. Pondok pesantren Al-Ittihad memiliki jamban/ toilet sebanyak 73 unit yang memakai kloset dan 5 tidak memakai kloset.

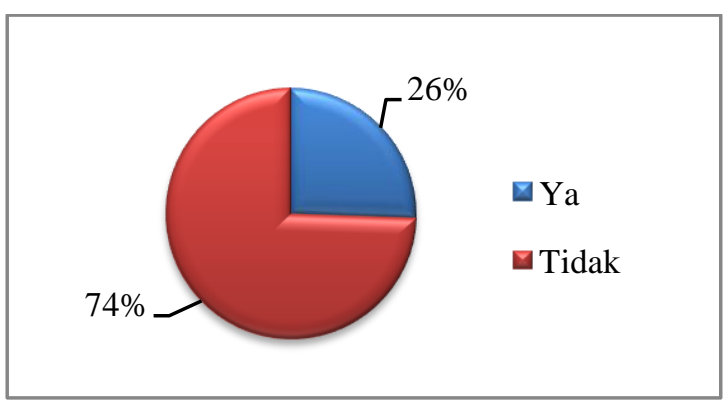

Gambar 6. Pernyataan responden tentang apakah jamban/toilet berada dalam satu tempat dengan tempat berwudhu atau mandi dan mencuci.

Gambar 6 memperlihatkan bahwa dari 94 responden yang menjawab bahwa jamban dengan tempat wudhu dipisahkan yaitu sebanyak $74 \%$. Karena di pondok pesantren memiliki kran air tersendiri untuk melakukan wudhu, dan yang menjawab bahwa jamban sama dengan tempat wudhu sebanyak $26 \%$. Sehingga dapat dianalisis bahwa kran yang ada di pondok pesantren kurang memadai, perlu ditambahkan terpisah dari area jamban. 


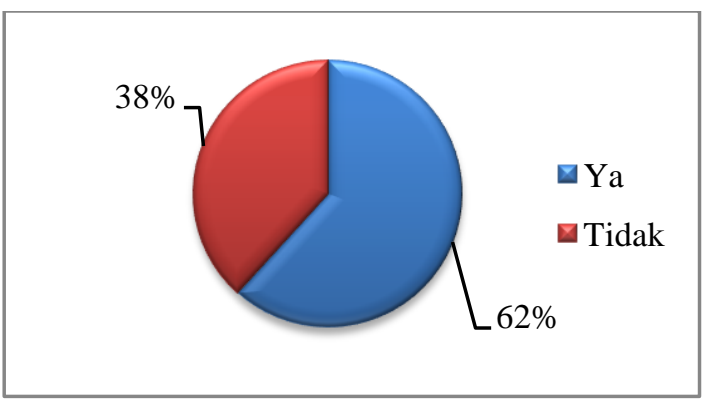

Gambar 7. Pendapat responden mengenai kecukupan jumlah jamban/toilet

Gambar 7 menunjukkan bahwa dari 94 responden yang menjawab bahwa jumlah jamban / toilet sudah cukup yaitu sebanyak 62\%, karena di pondok pesantren memiliki jumlah toilet sebanyak 78 unit, dan yang menjawab bahwa jumlah jamban/ toilet tidak cukup sebanyak 38\%. Sehingga dapat dianalisis bahwa di pondok pesantren jumlah jamban/ toilet belum cukup memadai untuk seluruh santri yang ada di pondok pesantren tersebut.

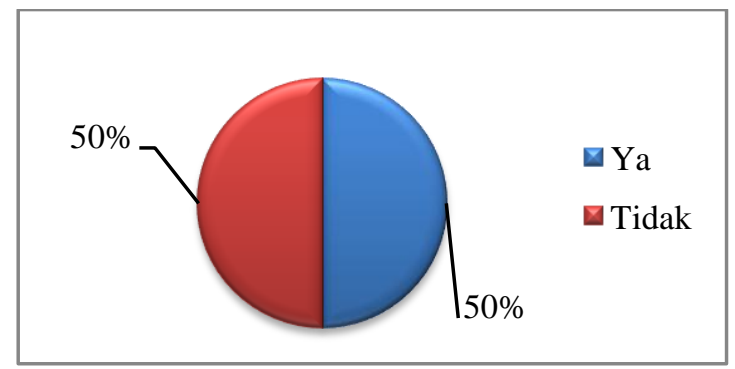

Gambar 8. Pendapat responden terhadap

kondisi jamban/toilet yang selalu bersih dan terawat.

Gambar 8 memperlihatkan bahwa dari 94 responden yang menjawab bahwa toilet tidak selalu dalam keadaan bersih yaitu sebanyak $50 \%$, dan yang menjawab bahwa toilet selalu dalam keadaan bersih sebanyak 50\%. Dari hasil tersebut dapat dianalisis bahwa jamban/ toilet tidak selalu dalam keadaan bersih. Sehingga perlu adanya jadwal piket/ gotong royong untuk pembersihan fasilitas sarana dan prasarana di Pondok pesantren Al-Ittihad.

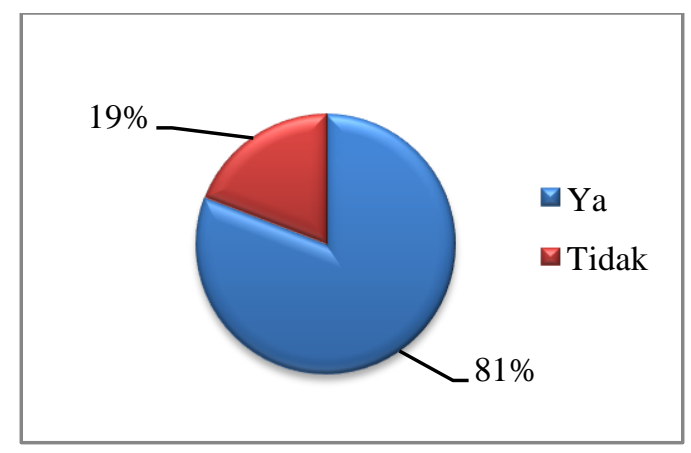

Gambar 9. Persepsi responden terhadap kelayakan jamban/toilet.

Gambar 9 memperlihatkan bahwa dari 94 responden yang menjawab bahwa bangunan toilet dalam keadaan layak yaitu sebanyak $81 \%$, karena di Pondok Pesantren Al-Ittihad, bangunan jamban/ toilet memberikan perlindungan bagi pemakainya dengan adanya dinding dan pintu. Sedangkan yang menjawab bahwa bangunan toilet dalam keadaan tidak layak sebanyak 19\%. Dikarenakan sebagaian toilet yang dimiliki pondok pesantren Al-Ittihad mengalami kerusakan dinding dan pintu. Sehingga perlu adanya perbaikan pada jamban/ toilet yang mengalami kerusakan.

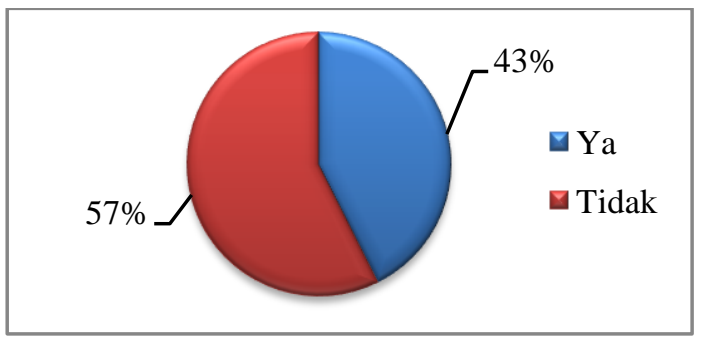

Gambar 10. Jawaban responden mengenai apakah air sabun (grey water) di salurkan ke lubang jamban.

Gambar 10 menunjukkan bahwa dari 94 responden yang menjawab air sabun dibuang ke lubang jamban yaitu sebanyak $43 \%$. Seharusnya air buangan sabun (deterjen) tidak boleh dibuang ke lubang jamban karena kandungan deterjen dapat membunuh bakteri pengurai yang dibutuhkan septic tank. Sedangkan yang menjawab bahwa air sabun tidak dibuang ke lubang jamban sebanyak 57\%. Namun 
penyaluran grey water ini diarahkan ke saluran drainase. Hal ini juga seharusnya tidak boleh dilakukan karena saluran drainase yang ada akan bermuara ke selokan maupun ke sungai. Akibatnya sungai tersebut akan tercemar. Sehingga perlunya pembuatan IPAL (komunal) atau dengan cara sederhana menanam tumbuhan penyerap limbah seperti jaringao, melati air maupun lili air.

\section{Analisis Sarana Drainase}

Beberapa kategori yang menjadi persepsi, pernyataan dan pendapat responden dalam kuisioner untuk fasilitas drainase bisa dilihat pada Gambar 11 - 13 .

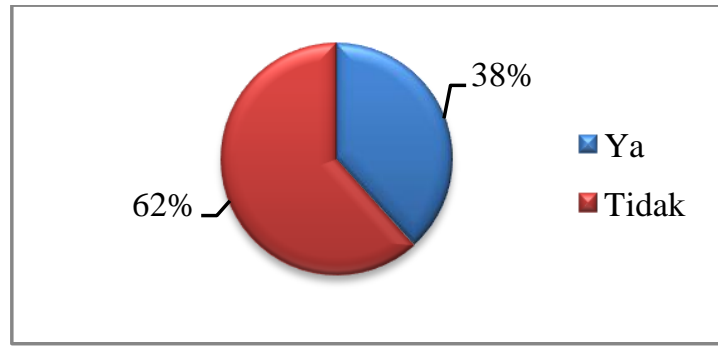

Gambar 11. Pernyataan responden mengenai terjadinya genangan saat musim hujan.

Gambar 11 menunjukkan bahwa dari 94 responden yang menjawab bahwa jika musim hujan terjadi banjir yaitu sebanyak $38 \%$, dan yang menjawab tidak sebanyak $62 \%$. Sehingga dapat dianalisis bahwa kemungkinan akses untuk drainase di pondok pesantren aliran airnya terhambat akibat sampah yang menyumbat dan lumpur/ tanah yang mengendap sehingga dimensi drainase berkurang untuk dapat menampung volume air hujan, dan mengakibatkan banjir/ genangan di Pondok Pesantren Al-Ittihad.

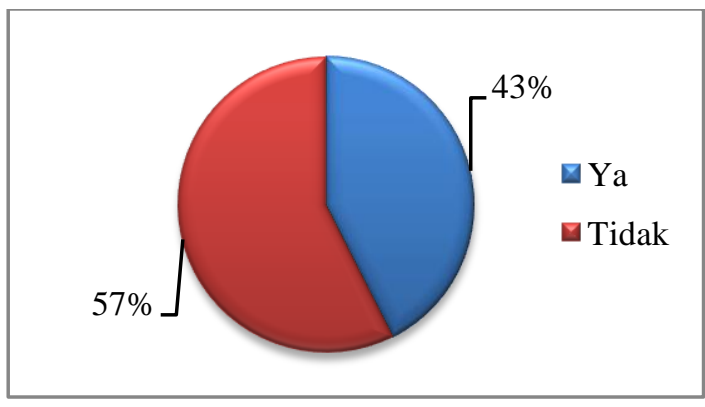

Gambar 12. Pernyataan responden tentang kondisi saluran drainase yang tersumbat.

Gambar 12 menunjukkan bahwa dari 94 responden yang menjawab bahwa saluran drainase ada yang tersumbat yaitu sebanyak $43 \%$, dan yang menjawab tidak sebanyak $57 \%$. Sehingga dapat dianalisis bahwa aliran air untuk masuk ke saluran drainase di pondok pesantren belum berjalan dengan baik di beberapa bagian.

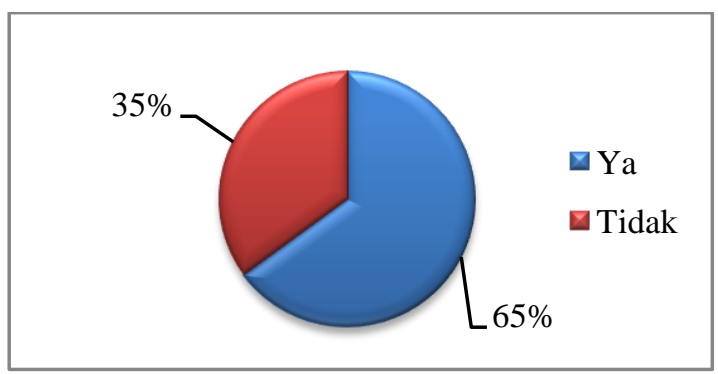

Gambar 13. Jawaban responden mengenai kondisi kelayakan/ terawatnya saluran drainase.

Gambar 13 memperlihatkan bahwa dari 94 responden yang menjawab bahwa saluran air dalam keadaan baik, layak dan terawat yaitu sebanyak 65\%, dan yang menjawab tidak sebanyak 35\%. Sehingga perlu adanya jadwal piket/ gotong royong untuk pembersihan fasilitas sarana dan prasarana di Pondok Pesantren AlIttihad.

\section{Analisis Sarana Persampahan}

Hasil pengumpulan informasi melalui kuisioner mengenai sarana pengelolaan sampah dapat dilihat pada Gambar $14-15$. 


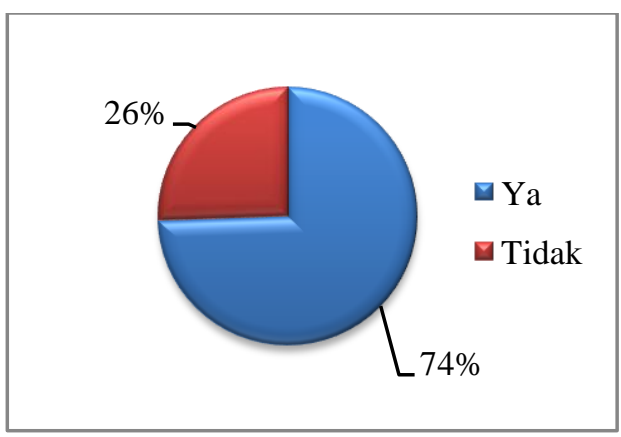

Gambar 14. Pernyataan responden mengenai pemilahan sampah.

Gambar 14 di atas menunjukkan bahwa dari 94 responden yang menjawab bahwa melakukan pemilahan sampah yaitu sebanyak $74 \%$, dan yang menjawab tidak sebanyak $26 \%$. Sehingga dapat dianalisis bahwa sistem pemilahan sampah yang dilakukan di pondok pesantren belum berjalan dengan baik/ rutin.

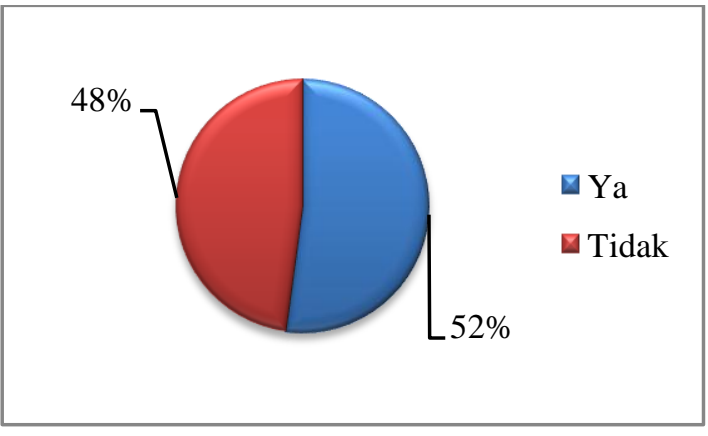

Gambar 15. Grafik kategori ada penumpukan sampah yang terlihat setiap harinya.

Gambar 15 menunjukkan bahwa dari 94 responden yang menjawab bahwa adanya penumpukan sampah yang terlihat setiap harinya yaitu sebanyak $52 \%$, dan yang menjawab tidak sebanyak $48 \%$. Sehingga dapat dianalisis bahwa pembuangan sampah yang dilakukan belum berjalan dengan rutin.

Tabel 2 memperlihatkan hasil pengamatan selama 3 hari dan pengukuran total berat timbulan sampah.
Tabel 2. Total Berat Sampah

\begin{tabular}{cccc}
\hline $\begin{array}{c}\text { Berat } \\
\text { Sampah } \\
\text { Perhari } \\
\text { Total } \\
(\mathbf{K g})\end{array}$ & $\begin{array}{c}\text { Berat } \\
\text { Sampah } \\
\text { Perorang } \\
(\mathbf{k g})\end{array}$ & $\begin{array}{c}\text { Berat } \\
\text { Tong } \\
\text { Sampah } \\
(\mathbf{k g})\end{array}$ & $\begin{array}{c}\text { Berat Total } \\
\text { Dengan } \\
\text { Pewadahan } \\
(\mathbf{k g})\end{array}$ \\
\hline 79,87 & 0,05 & 4,3 & 84,17 \\
\hline 105,7 & 0,07 & 4,3 & 110 \\
\hline 69,52 & 0,04 & 4,3 & 73,82 \\
\hline
\end{tabular}

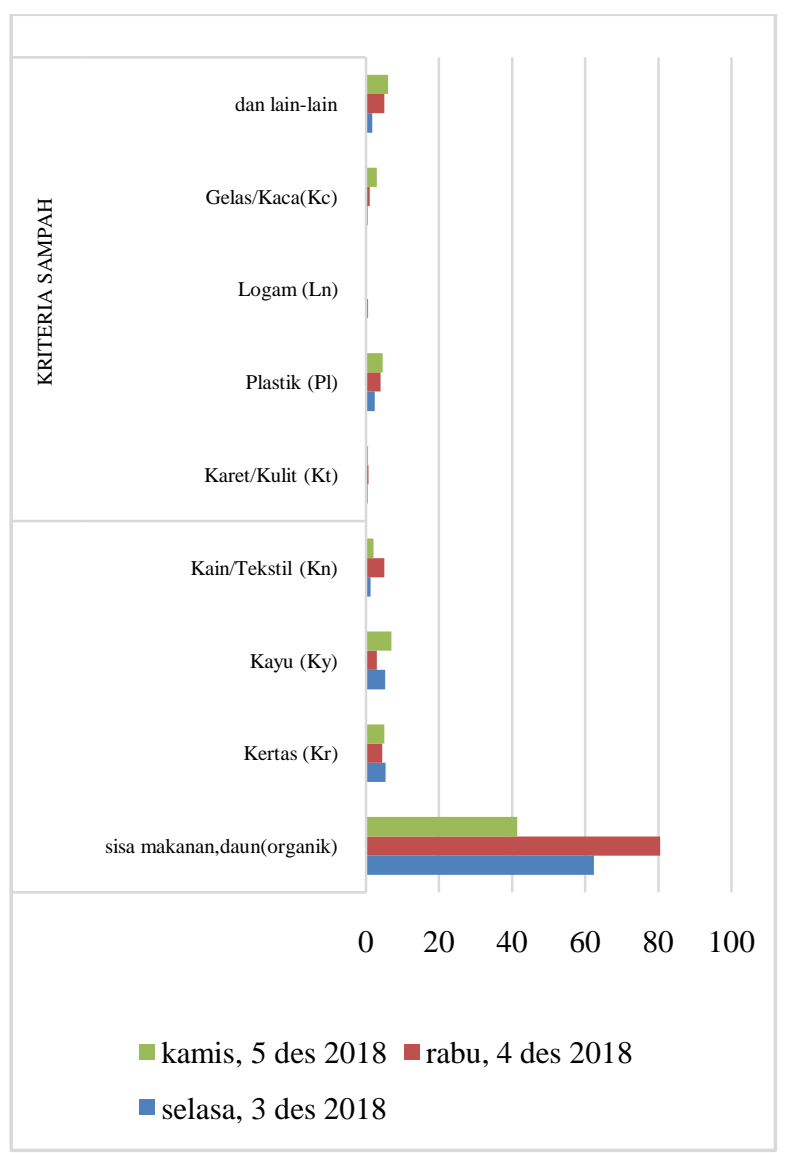

Gambar 16. Jenis timbulan sampah

Gambar 16 menunjukkan bahwa jenis sampah yang mendominasi adalah sisa makanan, daun, dan sampah organik lainnya. Hal ini disebabkan karena pondok pesantren memiliki juru masak bagi para santri dan melakukan kegiatan memasak sendiri. Dengan kondisi ini, maka sampah organik lebih dominan dibandingkan sampah kemasan yang sering timbul akibat pembelian makanan dari luar. Pada Hari Kamis 
para santri ada yang melakukan ibadah puasa. Sehingga sampah yang dihasilkan lebih rendah dari pada hari lainnya.

\section{Kesimpulan}

Penelitian ini menghasilkan beberapa temuan yaitu:

1. Secara kualitas, air bersih dirasakan memadai oleh penghuni pondok pesantren terutama karena adanya pengolahan air minum berupa unit RO dan desinfeksi UV.

2. Fasilitas jamban sudah memadai, namun perlu perbaikan kualitas dengan memisahkan lokasinya dari tempat berwudhu. Selain itu, terdapat penghuni yang merasa bahwa jumlah jamban masih belum mencukupi.

3. Saluran drainase yang terdapat di Pondok Pesantren Al-Ittihad dikatakan masih baik oleh mayoritas penghuni, namun perlu perawatan agar saluran tidak tersumbat sampah atau kotoran lainnya.
4. Pengelolaan sampah sudah diawali dengan pemilahan, namun penumpukan sampah masih terjadi, sehingga perlu adanya pengangkutan sampah yang lebih sering.

\section{Daftar Pustaka}

Chaerunnissa, C. (2014). Partisipasi Masyarakat dalam Program Penyediaan Air Minum dan Sanitasi Berbasis Masyarakat (PAMSIMAS) di KABUPATEN BREBES (Studi Kasus Desa Legok dan Desa Tambakserang Kecamatan Bantarkawung). Politika: Jurnal Ilmu Politik, Vol 5, No 2.

Ismillayli, N., Mardiana, L., Kurnianingsih, R., Hermanto, D., \& Fahrurazi. (2018). Penerapan Metode Filtrasi, Adsorpsi dan Reverse Osmosis untuk Pengolahan Air Sungai menjadi Air Siap Minum. J. Pij ar MIPA, Vol. XIII No.1: 60-63.

Sevilla, \& al, e. (2007). Research Methods. Quezon City: Rex Printing Company. 